\title{
REVISED Crafting minds and communities with Minecraft
}

\section{[version 2; peer review: 2 approved]}

\section{Benjamin C. Riordan, Damian Scarf}

Department of Psychology, University of Otago, Dunedin, 9054, New Zealand

\author{
V2 First published: 19 Sep 2016, 5:2339 \\ https://doi.org/10.12688/f1000research.9625.1 \\ Latest published: 09 Jan 2017, 5:2339 \\ https://doi.org/10.12688/f1000research.9625.2
}

\section{Abstract}

Minecraft is a first-person perspective video game in which players roam freely in a large three-dimensional environment. Players mine the landscape for minerals and use these minerals to create structures (e.g., houses) and mould the landscape. But can Minecraft be used to craft communities and minds? In this opinion piece, we highlight the enormous potential of Minecraft for fostering social connectedness, collaboration, and its potential as an educational tool. We highlight the recent use of Minecraft to aid socialization in individuals with Autistic Spectrum Disorder (ASD) and promote civic engagement via the United Nations Human Settlement Program. We further provide novel links between Minecraft and recent on work on the role of social cures and community empowerment in enhancing mental health, wellbeing, and resilience.

\section{Keywords}

Minecraft, Education, Gamification, Technology, Developmental Psychology

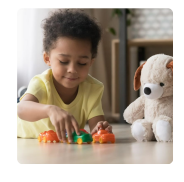

This article is included in the Developmental Psychology and Cognition gateway.

\section{Open Peer Review \\ Approval Status \\ 1 \\ 2 \\ version 2 \\ (revision) \\ 09 Jan 2017 \\ version 1 \\ 19 Sep 2016

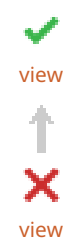 \\ 1. Mark Lorch, University of Hull, Hull, UK \\ 2. Ascensión Hernández-Encinas, University of Salamanca, Salamanca, Spain \\ Any reports and responses or comments on the article can be found at the end of the article.}


Corresponding author: Damian Scarf (damian@psy.otago.ac.nz)

Competing interests: No competing interests were disclosed.

Grant information: The author(s) declared that no grants were involved in supporting this work.

Copyright: ( 2017 Riordan BC and Scarf D. This is an open access article distributed under the terms of the Creative Commons Attribution License, which permits unrestricted use, distribution, and reproduction in any medium, provided the original work is properly cited. Data associated with the article are available under the terms of the Creative Commons Zero "No rights reserved" data waiver (CC0 1.0 Public domain dedication).

How to cite this article: Riordan $B C$ and Scarf D. Crafting minds and communities with Minecraft [version 2; peer review: 2 approved] F1000Research 2017, 5:2339 https://doi.org/10.12688/f1000research.9625.2

First published: 19 Sep 2016, 5:2339 https://doi.org/10.12688/f1000research.9625.1 


\section{REVISED Amendments from Version 1}

We now draw on social psychology literature to make more of an argument for the use of Minecraft to help craft communities and some potential limitations.

See referee reports
Minecraft is a first-person perspective sandbox game - a threedimensional, procedurally generated, Lego-like environment made up of blocks of different compounds (Duncan, 2011; Mojang, 2016). Players mine these compounds and re-place them to create various structures or shape the landscape. Minecraft has been purchased over 100 million times and in every country in the world (incl. Antarctica; Mojang, 2016). We think Minecraft is more than a global phenomenon, and may represent a critical and historical transition; an eminently popular videogame that is highly social and collaborative (Bainbridge, 2007; Entertainment Software Association, 2016; Granic et al., 2014; Przybylski, 2014), casting doubt on the depiction of video gamers as disconnected children and adolescents (Zimbardo \& Coulombe, 2016). While early videogame research focused predominantly on the negative impacts of gaming (Strasburger et al., 2010), researchers are now starting to focus on the positives (Lorch \& Mills, 2016). We believe that Minecraft is at the forefront of this change (Granic et al., 2014; Nebel et al., 2016).

Unlike other games, when played in its traditional settings, Minecraft has no aim or specific goals, which allows players the freedom to immerse themselves in their own narrative, build, create, and explore. Players can build alone, or join/create servers to play cooperatively. Given the creative nature of Minecraft and the open world environment, it is unsurprising that some have used the platform to create immersive worlds, artworks, and performances (Bukvic et al., 2014; Duncan, 2011). Importantly, Minecraft lends itself to socialization. The nature of the game has led to the formation of communities and groups that share and support creative creation. Given the move towards social and online gaming, it is unsurprising that a recent review found that videogame play is associated with social outcomes (Greitemeyer \& Mügge, 2014). But unlike other games, Minecraft may be used to actively promote socialization.

An example of this is Autcraft, a semi-private Minecraft server and online community formed around those with Autistic Spectrum Disorder (ASD; Ringland et al., 2016). Those with ASD often struggle with face-to-face social interactions, but they still express a desire to connect socially. Playing Minecraft can help these players meet their social goals and gain the positive effects of socialization (Ringland et al., 2016). Although the effectiveness of Autcraft on wellbeing has not been tested, ethnographic research has suggested that the platform has successfully promoted collaboration, socialization, and community. Ensuring that individuals maintain group memberships is critical in improving health and wellbeing (Holt-Lunstad et al., 2010; Jetten et al., 2012), and the Autcraft blueprint can be used to help other groups achieve this (Osmanovic \& Pecchioni, 2016). It is important to note, however, that Minecraft is likely best suited to facilitating, rather than replacing, in-person group based activities. For example, for disabled individuals who maybe largely house bound, Minecraft may provide a way to interact with fellow group members frequently; helping to keep groups together that may only meet occasionally in person. It will also be important for future studies to investigate whether Minecraft can imbue groups with the sense of belonging and acceptance that are critical to their benefits (Scarf et al., 2016a; Scarf et al., 2016b).

The collaborative nature of Minecraft can also promote prosocial behavior outside the videogame context (Gentile et al., 2009; Greitemeyer \& Mügge, 2014). For example, to harness the prosocial behavior Minecraft instils and to promote civic engagement, Minecraft partnered with the United Nations Human Settlement Program (UN-Habitat) to engage communities in planning urban public spaces (Block By Block, 2016). The program provided residents with Minecraft and computer access so they could cooperatively recreate their cities and show city planners how they want their cities to look. The ubiquity of Minecraft and ease of play makes it the perfect game to promote bottom-up approaches and engage and empower communities to reimagine their city spaces (Baba et al., 2016). The program has helped communities all over the world create parks, city squares, sidewalks, seawalls, and marketplaces and offers a novel way to engage youth in shaping their environments.

Beyond social applications, Minecraft actively promotes the problem solving skills, creativity, planning, and persistence skills necessary for future success. Employers are actively recruiting gamers from online videogame leaderboards (Carr-Chellman, 2016) and gamers' unique skills are credited with helping scientists solve complex problems (Cooper et al., 2010). Minecraft fosters these skills as the environment requires the player to interact with unfamiliar environments, experiment, calculate, plan ahead, and develop complex mental representations to understand the world. In fact, longitudinal research suggests that videogames are related to greater problem solving skills. For example, in a high school population, strategic videogame play predicted self-reported problem solving skills, which in turn predicted better academic grades (Adachi \& Willoughby, 2013). Research has also experimentally manipulated videogame play to determine whether this correlation is causal. When undergraduates were assigned to play a strategy based game (Portal 2), relative to a group that ironically played a brain-training game (Lumosity), the strategy group displayed a significantly greater improvement in problem solving and persistence (Shute et al., 2015).

To help educators craft minds in the class room, Minecraft released an updated version, Minecraft: Education Edition in November 2016 (Mojang, 2016). To launch off the platform laid by MinecraftEDU, the updated version includes features to facilitate classroom participation. The use of a commercial game like Minecraft in education may not only increase motivation for learning, but allow students to take a more active role in their education. Already, a number of educators have taken advantage of the collaborative nature of Minecraft to plan immersive lessons, and homework in subjects such as math, earth and ocean science, chemistry, molecular biology, and history (for a review see Nebel et al., 2016). Outside the classroom, platforms already exist to help students explore geology or the stories behind famous art (British Geological Society, 2017; 
Tate Modern, 2017). Although there are few studies on using Minecraft in the classroom, educators have consistently reported that Minecraft has improved interest and motivation for learning (Nebel et al., 2016). For example, to measure the effectiveness of Minecraft as a teaching tool, one $7^{\text {th }}$ grade class was taught with Minecraft and another with traditional lecture based learning. Both groups showed improvement, however, post-tests indicated those who had been taught with Minecraft performed significantly better (Wang \& Towey, 2013). Unfortunately, this is one of the few studies to use an adequate control group to test the effectiveness of Minecraft in the classroom. Despite this, we believe that the functions added to Minecraft Education Edition will allow Minecraft to become a mainstay in education and help craft minds.

While more empirical data is needed, the use of Minecraft to foster socialization, engage and empower communities, and enhance students' interest in education and creation suggests that Minecraft is crafting minds and opening a new chapter in video game research.

\section{Author contributions}

BR wrote the initial draft of the manuscript and provided scope for the manuscript. DS conceived the idea and co-wrote the initial draft of the manuscript. Both authors agreed to the final content.

\section{Competing interests}

No competing interests were disclosed.

\section{Grant information}

The author(s) declared that no grants were involved in supporting this work.
Adachi PJ, Willoughby T: More than just fun and games: the longitudinal relationships between strategic video games, self-reported problem solving skills, and academic grades. J Youth Adolesc. 2013; 42(7): 1041-1052. PubMed Abstract | Publisher Full Text

Baba C, Kearns A, Mclntosh E, et al.: Is empowerment a route to improving mental health and wellbeing in an urban regeneration (UR) context? Urban Stud. 2016.

Publisher Full Text

Bainbridge WS: The scientific research potential of virtual worlds. Science. 2007; 317(5837): 472-476.

PubMed Abstract | Publisher Full Text

Block By Block. Blockbyblock.org. 2016; [Accessed July 3, 2016]

Reference Source

British Geological Society: GB Geology with Minecraft. 2017. [Accessed January 1, 2017]

Reference Source

Bukvic II, Cahoon C, Wyatt A, et al:: OPERAcraft: Blurring the lines between real and virtual. Ann Arbor, MI: Michigan Publishing, University of Michigan Library. 2014; 2014.

Reference Source

Carr-Chellman A: Why video games shouldn't freak parents out. 2016;

[Accessed July 3, 2016]

Reference Source

Cooper S, Khatib F, Treuille A, et al.: Predicting protein structures with a multiplayer online game. Nature. 2010; 466(7307): 756-760.

PubMed Abstract | Publisher Full Text | Free Full Text

Duncan SC: Minecraft, beyond construction and survival. Well Played: $A$ journal on video games, value and meaning. 2011; 1(1): 1-22.

Reference Source

Entertainment Software Association: Essential facts about the computer and video game industry. 2016; [Accessed July 3, 2016].

Reference Source

Gentile DA, Anderson CA, Yukawa S, et al: The effects of prosocial video games on prosocial behaviors: International evidence from correlational, longitudinal, and experimental studies. Pers Soc Psychol Bull. 2009; 35(6): 752-763.

PubMed Abstract | Publisher Full Text | Free Full Text

Granic I, Lobel A, Engels RC: The benefits of playing video games. Am Psychol. 2014; 69(1): 66-78.

PubMed Abstract | Publisher Full Text

Greitemeyer T, Mügge DO: Video games do affect social outcomes: a metaanalytic review of the effects of violent and prosocial video game play. Pers Soc Psychol Bull. 2014; 40(5): 578-589.

PubMed Abstract | Publisher Full Tex

Holt-Lunstad J, Smith TB, Layton JB: Social relationships and mortality risk: a meta-analytic review. PLoS Med. 2010; 7(7): e1000316.

PubMed Abstract | Publisher Full Text | Free Full Text

Jetten J, Haslam C, Haslam SH: The social cure: Identity, health and well-being.
Hove, England: Psychology Press, 2012

Reference Source

Lorch M, Mills J: How could help teach chemistry's building blocks of life. Chemistry in Australia. 2016; 20-22.

Reference Source

Mojang: Minecraft. 2016.

Reference Source

Nebel S, Schneider S, Rey GD: Mining learning and crafting scientific experiments: a literature review on the use of minecraft in education and research. Journal of Educational Technology \& Society. 2016; 19: 355-366. Reference Source

Osmanovic S, Pecchioni L: Beyond Entertainment: Motivations and Outcomes of Video Game Playing by Older Adults and Their Younger Family Members.

Games and Culture 2015; 11(1-2): 130-149.

Publisher Full Text

Przybylski AK: Electronic gaming and psychosocial adjustment. Pediatrics. 2014; 134(3): e716-e722.

PubMed Abstract | Publisher Full Text

Ringland KE, Wolf $\mathrm{CT}$, Faucett $\mathrm{H}$, et al.: "Will I always be not social?":

Re-Conceptualizing Sociality in the Context of a Minecraft Community fo Autism. Proceedings of ACM CHI Conference on Human Factors in Computing Systems. 2016; 1256-1269.

Publisher Full Text

Scarf D, Hayhurst JG, Riordan BC, et al:: Increasing resilience in adolescents: the importance of social connectedness in adventure education programs.

Australas Psychiatry. 2016a; pii: 1039856216671668.

PubMed Abstract | Publisher Full Text

Scarf D, Moradi S, McGaw K, et al:: Somewhere I Belong: Long-term increases in adolescents' resilience are predicted by perceived belonging to the in-group. Br J Soc Psychol. 2016b; 55(3): 588-599.

PubMed Abstract | Publisher Full Text

Shute V, Ventura M, Ke F: The power of play: The effects of Portal 2 and Lumosity on cognitive and noncognitive skills. Computers \& Education. 2015 80: 58-67.

Publisher Full Text

Strasburger VC, Jordan AB, Donnerstein E: Health Effects of Media on Children and Adolescents. Pediatrics. 2010; 125: 756-767.

PubMed Abstract | Publisher Full Text

Tate Modern: Tate Worlds. 2017. [Accessed January 1, 2017].

Reference Source

Wang T, Towey D: A Mobile Virtual Environment game approach for improving student learning performance in integrated science classes in Hong Kong International Schools. IEEE International Conference on: Teaching, Assessment and Learning for Engineering (TALE). 2013.

Publisher Full Text

Zimbardo P, Coulombe ND: Man Disconnected: How technology has sabotaged what it means to be male. London, England: Rider, 2016. 


\section{Open Peer Review}

\section{Current Peer Review Status:}

\section{Version 2}

Reviewer Report 30 March 2017

https://doi.org/10.5256/f1000research.11434.r21361

(C) 2017 Hernández-Encinas A. This is an open access peer review report distributed under the terms of the Creative Commons Attribution License, which permits unrestricted use, distribution, and reproduction in any medium, provided the original work is properly cited.

\section{Ascensión Hernández-Encinas}

Department of Applied Mathematics, University of Salamanca, Salamanca, Spain

This paper presents the use of Minecraft by individuals with ASD, with others. From our point of view there are some missing aspects that could improve the paper. This is only an introduction about the use of the program in the classroom. This kind of paper should include more specific aspects of the use of that tool in this adequate environment. Some specific results would be appreciated, to test the suitability of Minecraft.

Competing Interests: No competing interests were disclosed.

I confirm that I have read this submission and believe that I have an appropriate level of expertise to confirm that it is of an acceptable scientific standard.

Reviewer Report 01 February 2017

https://doi.org/10.5256/f1000research.11434.r19056

(C) 2017 Lorch $\mathbf{M}$. This is an open access peer review report distributed under the terms of the Creative Commons Attribution License, which permits unrestricted use, distribution, and reproduction in any medium, provided the original work is properly cited.

\section{Mark Lorch}

Department of Chemistry, University of Hull, Hull, UK

I would like to thank the authors for addressing my earlier comments and adjusting their manuscript accordingly. The latest version presents a clear overview of some of the ways that Minecraft has been used in educational and provides context though reference to existing video game research.

The additional insight into the authors' opinions are welcomed. 
I am happy to now approve the paper.

Competing Interests: No competing interests were disclosed.

I confirm that I have read this submission and believe that I have an appropriate level of expertise to confirm that it is of an acceptable scientific standard.

\section{Version 1}

Reviewer Report 24 October 2016

https://doi.org/10.5256/f1000research.10369.r17059

(c) 2016 Lorch M. This is an open access peer review report distributed under the terms of the Creative Commons Attribution License, which permits unrestricted use, distribution, and reproduction in any medium, provided the original work is properly cited.

\section{Mark Lorch}

Department of Chemistry, University of Hull, Hull, UK

The article is a very brief introduction to some uses of Minecraft outside of its core gamer base. The authors highlight some interesting projects, but do not dicuss them at any length.

Beyond providing a handful of examples no real attempt has been made to discuss how Minecraft can or might be used to craft minds and communities. Nor do the authors express much of an opinion on the topic.

Furthermore some fundamentals and high profile attempts to use Minecraft as an educational tool projects have been overlooked. For example the authors imply that the first versions of Minecraft designed for educational uses was launched in September 2016. However MinecraftEDU has been available since 2011. Other educational projects such work by the Royal Geological Society, the Tate Modern are not mentioned.

The article does cover a very interesting and rich area for which I would like to see a comprehensive review or opinion piece. This article is a good start however much more depth, both in terms of examples, discuss and opinion is needed.

Competing Interests: No competing interests were disclosed.

I confirm that I have read this submission and believe that I have an appropriate level of expertise to state that I do not consider it to be of an acceptable scientific standard, for reasons outlined above. 


\section{Damian Scarf,}

We thank the reviewer for their thoughts and suggestions and address some of their comments below. We hope that our amendments to the manuscript meet their concerns.

1. The article is a very brief introduction to some uses of Minecraft outside of its core gamer base. The authors highlight some interesting projects, but do not discuss them at any length. Beyond providing a handful of examples no real attempt has been made to discuss how Minecraft can or might be used to craft minds and communities. Nor do the authors express much of an opinion on the topic.

Unfortunately, we are limited by the amount we can say due to a tight word limit. The aim was not to discuss these points at great length but to provide a succinct and accessible overview of the promise of Minecraft in a number of areas. Very few studies using Minecraft have used adequate control groups, so where possible we have drawn on other videogame literature that has used more robust methodologies. At this stage we believe the research is not fleshed out enough for a large scale review or meta-analysis.

However, we agree that we may be light on an opinion and make our thoughts more explicit. We now draw on social psychology literature to make more of an argument for the use of Minecraft to help craft communities and some potential limitations.

1. Furthermore some fundamentals and high profile attempts to use Minecraft as an educational tool projects have been overlooked. For example the authors imply that the first versions of Minecraft designed for educational uses was launched in September 2016. However MinecraftEDU has been available since 2011. Other educational projects such work by the Royal Geological Society, the Tate Modern are not mentioned.

We thank the reviewer for these suggestions and have added in more high profile uses of Minecraft.

We agree we have made an error in implying that Minecraft Education Edition is the first being used for education. This was not our intention. We make this point more explicit.

1. The article does cover a very interesting and rich area for which I would like to see a comprehensive review or opinion piece. This article is a good start however much more depth, both in terms of examples, discuss and opinion is needed.

We agree that this is an important area and are excited to see some more results. We hope more pieces like these will compel other researchers to run randomised controlled trials to address some of the gaps in the literature. We believe Minecraft can and should be more than just a 'cool' way to present education.

Competing Interests: No competing interests were disclosed. 
The benefits of publishing with F1000Research:

- Your article is published within days, with no editorial bias

- You can publish traditional articles, null/negative results, case reports, data notes and more

- The peer review process is transparent and collaborative

- Your article is indexed in PubMed after passing peer review

- Dedicated customer support at every stage

For pre-submission enquiries, contact research@f1000.com 